\title{
Consistency of the Wind Power Industry, Including the Process of Sustainable Planning and Space Management
}

\author{
Tomasz Malczyk* \\ Architecture and Urban Planning, University of Applied Science in Nysa, Poland \\ Institute of Landscape Architecture, University of Environmental and Life Sciences in Wrocław
}

Received: 19 June 2015

Accepted: 8 November 2015

\begin{abstract}
Development of the wind power industry in Poland is more and more dynamic, which is proving interest in obtaining more energy from renewable sources. It is one of more efficient and attractive forms of eco-energetic activity. At the same time, wind energy is a unique, dominant spatial form that clearly influences the quality of the landscape. This is a reason why it frequently evokes dichotomous feelings. Not questioning the need for existence of this branch of energy production, and even seeking the possibility of its further sustainable development, it is reasonable to develop a consistent assessment method to influence eco-energetic investments in the landscape and environment. It will enable defining, testing, and creating planning methods to facilitate and implement policy of broadly-understood sustainable development.

In the article design capabilities and implementation possibilities of projects, called wind farms, were discussed on the basis of examples of the existing and planned projects in Poland. Merging scientific fields related to renewable energy sources and spatial planning requires development of method pursuing the idea of environmental protection and sustainable development, both of eco-energetic and spatial nature.

The purpose of this article is to demonstrate the need to define research areas whose solution allows us to determine a coherent methodology for the evaluation and location of wind farms in the process of sustainable planning and space management.
\end{abstract}

Keywords: sustainable development, spatial planning, landscape, wind energy

\section{Introduction}

The subject matter of our article is related to multidimensional space rooted in different science domains, which themselves constitute achievements creating recognized cognitive, implementative and, above all, empirical

*e-mail: tomasz.malczyk@pwsz.nysa.pl values. Therefore, the multi-dimensionality of the issue requires a broad view with a holistic analytical approach constituting the foundation of exploration because the final problem is related to the macro space, both in the energetic, environmental, economical, economic, and social as well as the aesthetic, landscape, cultural and, firstly, planning perspective $[1,2]$.

Development of the wind power industry, like any other form of human activity, has resulted in a specific pres- 
sure on the environment which, taking into consideration the recognized principles of sustainable development, results frequently in dichotomous reactions and feelings [35]. Wind farms constitute establishments of a considerable spatial size, which is related at the same time to the vertical and horizontal side. As a result, eco-energetic anthropopressure caused by wind power plants is of particular value, which directly affects the balance between the pejorative and meliorative perceptions of the project [6-8]. It is a result of a consistent approach to implementation of the basic and undisputed values relating to sustainable development [9-12], that co-create the need for respect for the energy and its being obtained from the renewable sources [13-17], at the same time preserving balance and broadly understood spatial order with special consideration of society and environment.

Additionally, the entire issue may take the form of point, surface, line, or a concentrated pressure, as well as act globally, regionally, locally and, first of all, topically [18]. It results in a series of cause-and-effect relations, exemplifying most commonly with accruing new phenomena, sometimes of direction and scale that are difficult to predict $[2,19]$. Therefore, there exists a need for taking anticipative actions related to this subject aiming at identification of implementation methods of environmental and economic message of the wind power industry, at the same time taking into consideration the social, aesthetic, cultural, identity, and development aspects [20-25].

Globally, the wind energy industry has been evolving since the 1980s. However, among the largest producers of this kind of energy are the U.S.A., China, Australia, Germany, Spain, the United Kingdom, Portugal, and Denmark [26-30]. In Poland the wind power industry sector has been developing successfully since the beginning of the 2000s, and more intensely since ca. 2005 [31]. Wind farms are developed in the areas that meet a number of requirements and normative terms relating to, among others, proper wind capacity $[32,33]$ as well as area roughness $[28,32,34]$ associated with orography (appropriate wind zone) [35]. As a result, wind farms should be located in an open, flat, or elevated area with no buildings at a distance of at least $500 \mathrm{~m}$, with no high greenery and hills inhibiting air movement. At the same time, the demand for power plants of high capacity increases, which most often results in increased tower height and a broad span of rotor arms [27]. The whole constitutes an unsurpassed dominant in the environment and landscape, which, taking into consideration the connection with the aforementioned location conditions related to obtaining high farm efficiency, intensifies its influence on open landscape and affects its change, perception, and final quality [36-39].

Thus, there is a measurable, endogenous need for interdisciplinary co-existence and consistent cooperation of many industries related to the wind power industry, by creating instruments of holistic evaluation of location of wind farms and tools for establishing the farm and thereby reducing its influence on the environment and at the same time developing this eco-energetic industry. Owing to the large-area visual impact of wind power plants, it is advised to intensively cooperate for the development of methods of planning and spatial development, in the urban, rural, architectural, and environmental as well as landscape planning perspectives [1-3, 5, 31, 40, 41]. Indicated areas interpenetrate and should not be a clump of accidental overlapping activities, but an effect of systematic exploration of this topic, scientific prediction, and praxeological decisions.

\section{Materials and Methodology}

\author{
Research Methods
}

Our article has been embedded on applied research areas related to the assessment of the impact on environmental, landscape, and spatial values of wind power industry projects. The applied methodology included the following cognitive instruments:

1. A value matrix by Bajerowski, enabling analysis, on the basis of maps, of the location dependencies of the wind farm, buildings, and areas important due to their environmental, cultural, and aesthetic features [42].

2. Wejchert's impression curve (evaluating emotions) [43].

3. Viewpoints for evaluating places particularly important for the analysed area [44].

4. Visual Impact Evaluation Matrix (VIEM), regarding evaluation of location dependencies between wind park, buildings, and locations of power plants [45].

5. Valorization of rural monuments enabling assessment of cultural values [46].

6. Comparative analysis of panoramas [47].

Finally we analyzed existing and planned land use plans, especially taking into account sustainable development, ecology, cultural heritage, and the needs of residents with planed locations of several wind farms.

\section{Profile of Research Area}

The research was conducted in two phases of growing complication. In phase one for the purpose of comparison a general analysis of existing wind farms was conducted. The wind farms were located in:

a) Jagniątkowo Wind Farm in northwestern Poland (West Pomeranian Province) near Szczecin on a flat moraine highland $10 \mathrm{~m}$ above sea level.

b) Kamieńsk Wind Farm in central Poland (Łódź Province) near Równina Piotrkowska, $386 \mathrm{~m}$ above sea level on a 195-meter-high artificial hill (the area is predominantly rolling, with clear rises and lows).

c) Lipniki Wind Farm in southwestern Poland (Opolskie Province) at Wzgórza Niemczańsko-Strzelińskie near Sudetic Foreland (320 m above sea level, very diverse land, mountain ranges).

The second phase includes the analysis of the planned location for a new Lubrza Wind Farm, which may be connected to the other farms, e.g., Biała Wind Farm. The entire complex is located in the southeastern part of Po- 
land (Opolskie Province), which includes Płaskowyż Głubczycki, located between Kotlina Raciborska (on the northeastern side) and Góry Opawskie (on the southwestern side). From the northwestern side this region is adjacent to Równina Niemodlińska [35]. The whole is located at a height of $230 \mathrm{~m}$ above sea level. In this area, western and northwestern winds prevail [48].

\section{Results and Discussion}

The first part includes existing wind farms that were built in Poland taking into consideration various locations, i.e., in the northern, central and southern strips. They represent the most common location of wind power stations, taking into account first of all three basic values: wind capacity zones, terrain, building structure, and planned land use [32, 35, 48, 49] (Fig. 1). Additionally, the location of wind farms and their spatial impact on the environment (including landscapes as well as the possibility of spatial planning and spatial development), were assessed from a distance characterized by the greatest pressure, i.e., from 3 to $5 \mathrm{~km}$ counting from extreme power plant, which was confirmed in the subject literature $[39,41,50]$ and in our own study $[2,6]$.

Jagniątkowo Wind Farm is the northernmost (Równina Goleniowska), located near Zalew Szczeciński. The farm was established in 2007 within the Kamieński District in Wolin Commune [2]. It consists of 17 turbines with a capacity of more than $30 \mathrm{MW}$ (a mid-sized farm [41]); tower height $80 \mathrm{~m}$, rotor diameter $80 \mathrm{~m}$. The farm is located near the towns Recław, Jagniątkowo, and Wiejkowo (Fig. 2). The rhythmicity of the establishment occurring in setting of particular power stations intermingles with greenery between power plant rows. Lack of background competing with the whole in the form of the natural rise (mountain) or higher building, as well as greenery along transport routes surrounding power stations, results in the farm being perceived as an interesting engineering estab-

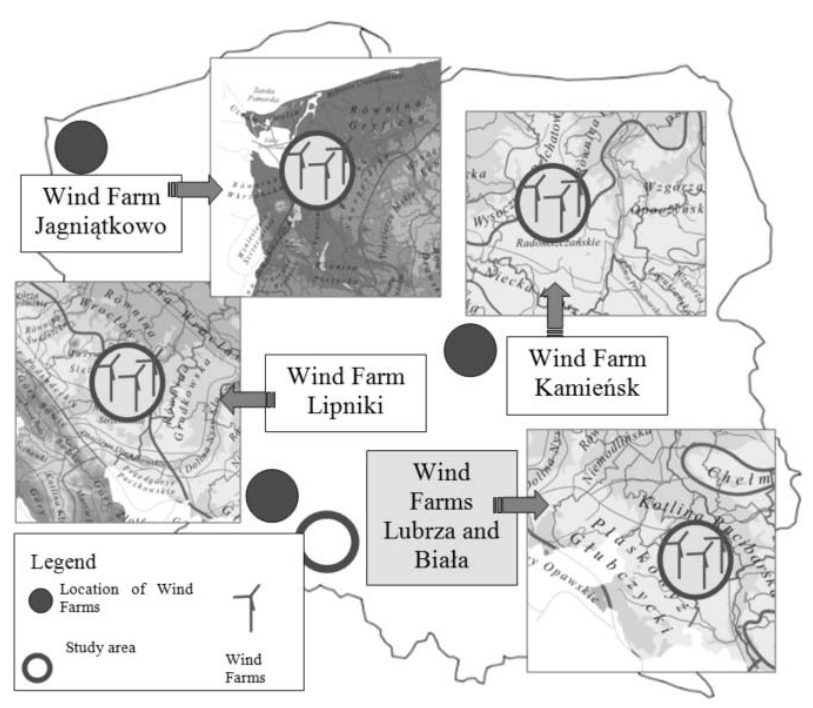

Fig. 1. Location of the range of the study. Own elaboration. lishment of alleviated reception gently embedded into its natural environment.

Another example is Kamieńsk Wind Farm located in central Poland on Góra Kamieńsk, constituting the reclaimed KWB Bełchatów dumping ground. This is a midsized farm, which consists of 15 turbines of total capacity of $30 \mathrm{MW}$; turbine total height $125 \mathrm{~m}[2,41]$. The farm is most visible from the side of the Katowice-Łódź-Warsaw route, while its visual impact is limited substantially along with closing in on the power station. It is caused by a perfect location of the establishment that is surrounded by a dense strip and high greenery. The farm is visible only in its immediate vicinity, but its comprehensive reception is difficult as from below only extreme turbines can be seen. Proper land use of the terrain under and next to the farm must be emphasized. Hiking and cycling routes and overlooks have been created. A ski center is being developed at the northern slope of the mountain (Fig. 3).

A negative example of location of a wind power station is Lipniki WF, which was built in 2011 on Wzgórza Niemczańsko-Strzelińskie, close to Równina Grodkows$\mathrm{ka}$. It is a mid-sized farm with 15 turbines of total power of $37.5 \mathrm{MW}$; total height of the turbine $126 \mathrm{~m}[2,41]$. The farm is located in an area of a very attractive landscape. Its height, as well as being situated $320 \mathrm{~m}$ above sea level and the diverse environment of variable heights, make it perfectly visible from even $20-30 \mathrm{~km}$, especially from the northeast, from the area of Równina Grodkowska [2, 35, 39]. Additionally, at a distance of ca. $30 \mathrm{~km}$ from of the farm, in the southern part, there is Przedgórze Sudeckie, constituting a natural background for Lipniki WF. The farm itself has an unfavourable (from the point of view of space organization) distribution of turbines because they are scattered in the area of ca. 162 ha (taking into account power station size, at least $400 \mathrm{~m}$ distances between turbines, and its linear spreading into three groups of several turbines). Particularly severe is parallelism of the system in relation to the mountain range, which can be observed from towns and routes located in the northern part of the establishment (Fig. 4). This impact is felt also in urban areas and areas of cultural value [1, 2, 4, 20, 22, 31] (Fig. $5)$, and in particular is relevant for the areas located at the boundaries of towns of the highest development potential (land available for construction purposes) [3, 5, 40].

In the case of presented examples the methodology of enterprise establishment should be prepared especially precisely in cases of wind farms. The issue is important as it affects an area for a long period of time (e.g., 30 years). It does not disappear by itself, but requires financial outlays and project activities resulting in adaptation of land for construction of the farm or for similar or new enterprises in the future. Subjects related to the location of wind power stations are raised in the reports concerning the impact of wind farms on the environment. The issue is most often discussed in the context of preservation of the state of the natural environment. They refer to a small extent to the protection of cultural heritage, landscape, or influence of the designed wind farm on urban and rural development of the town [51-53]. Thus, it seems justified to take 


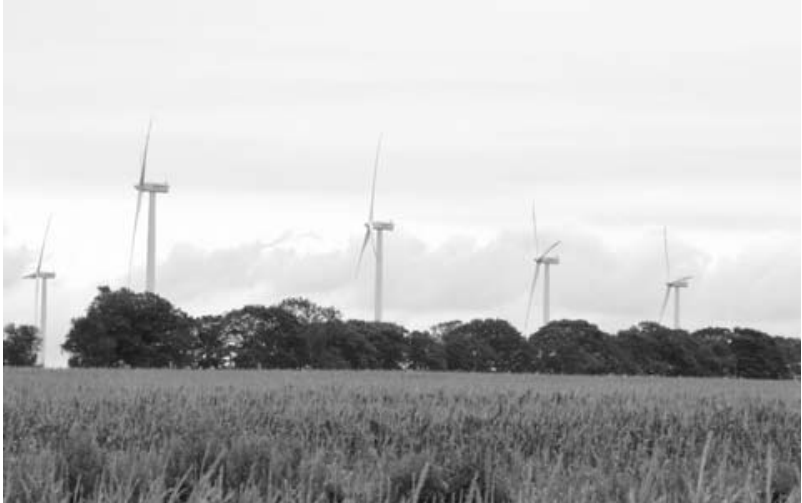

Fig. 2. Jagniątkowo Wind Farm. Own elaboration.

advantage of the constitutive right of self-determination directly or by appropriate administrative bodies, which should base their actions on applications arising from the scientific exploration of the subject and from previous experience.

A good example and, at the same time, a measurable study area are wind farms, which have not been built yet, but have all the documentation for obtaining a permit for construction. Such is the case of the proposed Lubrza Wind Farm [54] at Płaskowyż Głubczycki, under the strip between Koltlina Raciborska (northeastern side) and Góry Opawskie (southwestern side), adjacent to the Czech border. From the northwestern side, this region is adjacent to

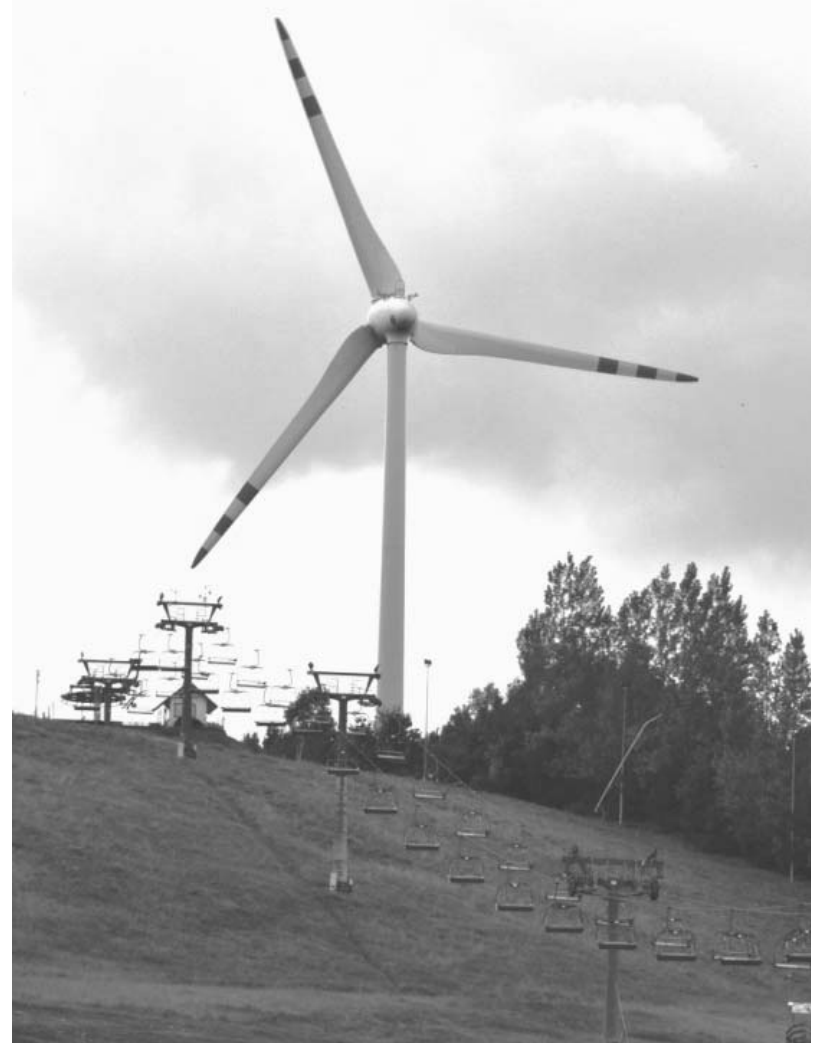

Fig. 3. Kamieńsk Wind Farm. View of the ski station. Own elaboration.

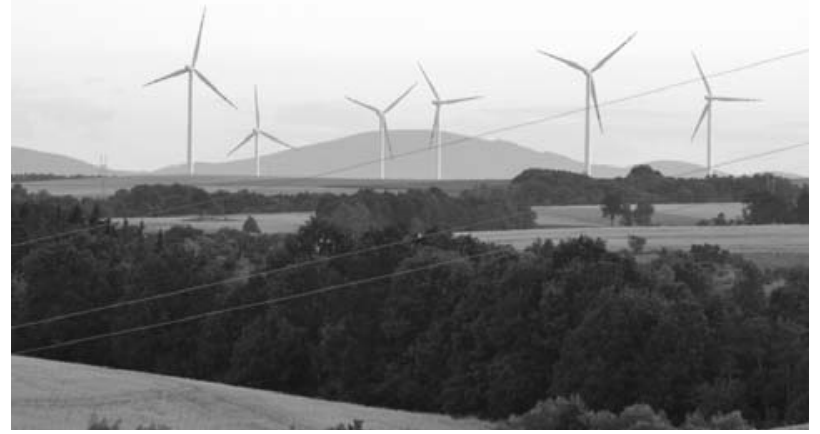

Fig. 4. Lipniki Wind Farm. View of Przedgórze Sudeckie. Own elaboration.

Równina Niemodlińska [35]. The whole wind farm is to be located at a height of $230 \mathrm{~m}$ above sea level. Twenty-nine turbines are planned ( $3 \mathrm{MW}$ power each), and height of the tower of power station will be ca. $130 \mathrm{~m}$. The farm will qualify as large [41], and due to its area it will be located within the Lubrza Commune, in the vicinity of the towns of Lubrza, Prężynka, Laskowice, and Nowy Browiniec [54]. It will be composed of three parts (A, B, and C) (Fig. 6). In the future, however, location shall be extended by further power stations that are planned independently by the neighboring Biała Commune (part D) [55].

In total, 17 wind turbines are planned for Biała Wind Farm located between the towns Browiniec - Rostko-
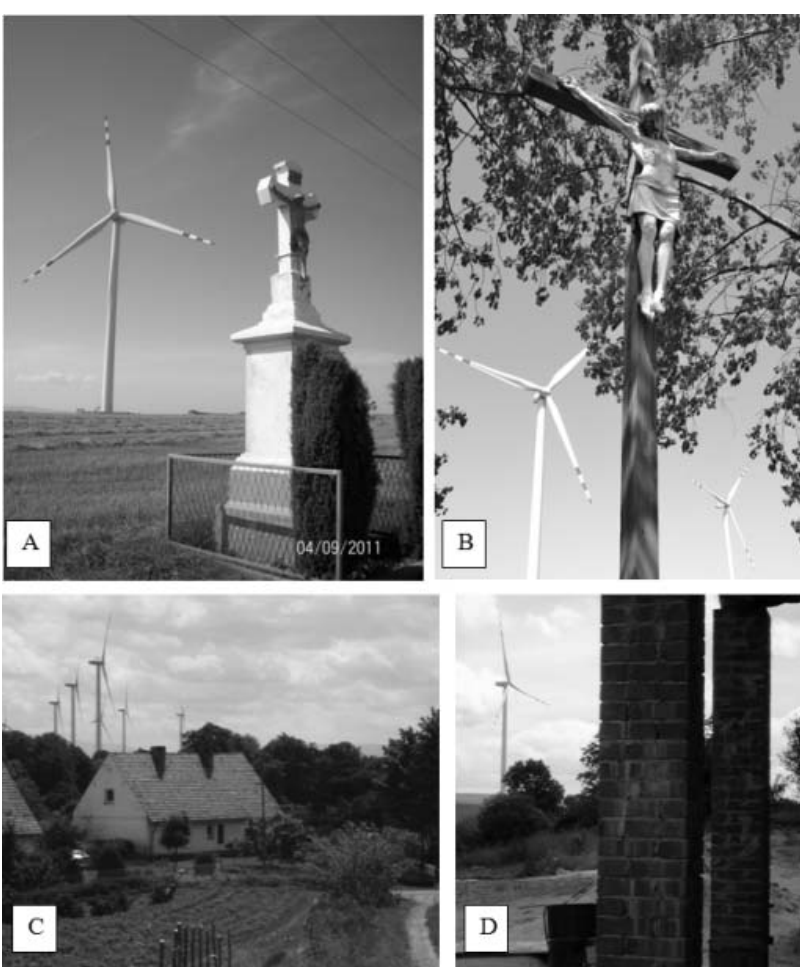

Fig. 5. Lipniki Wind Farm. Place of religious worship, core of identity of the society and of the place (A and B), developed areas (C), and new buildings in front of the wind farm (D). Own elaboration. 


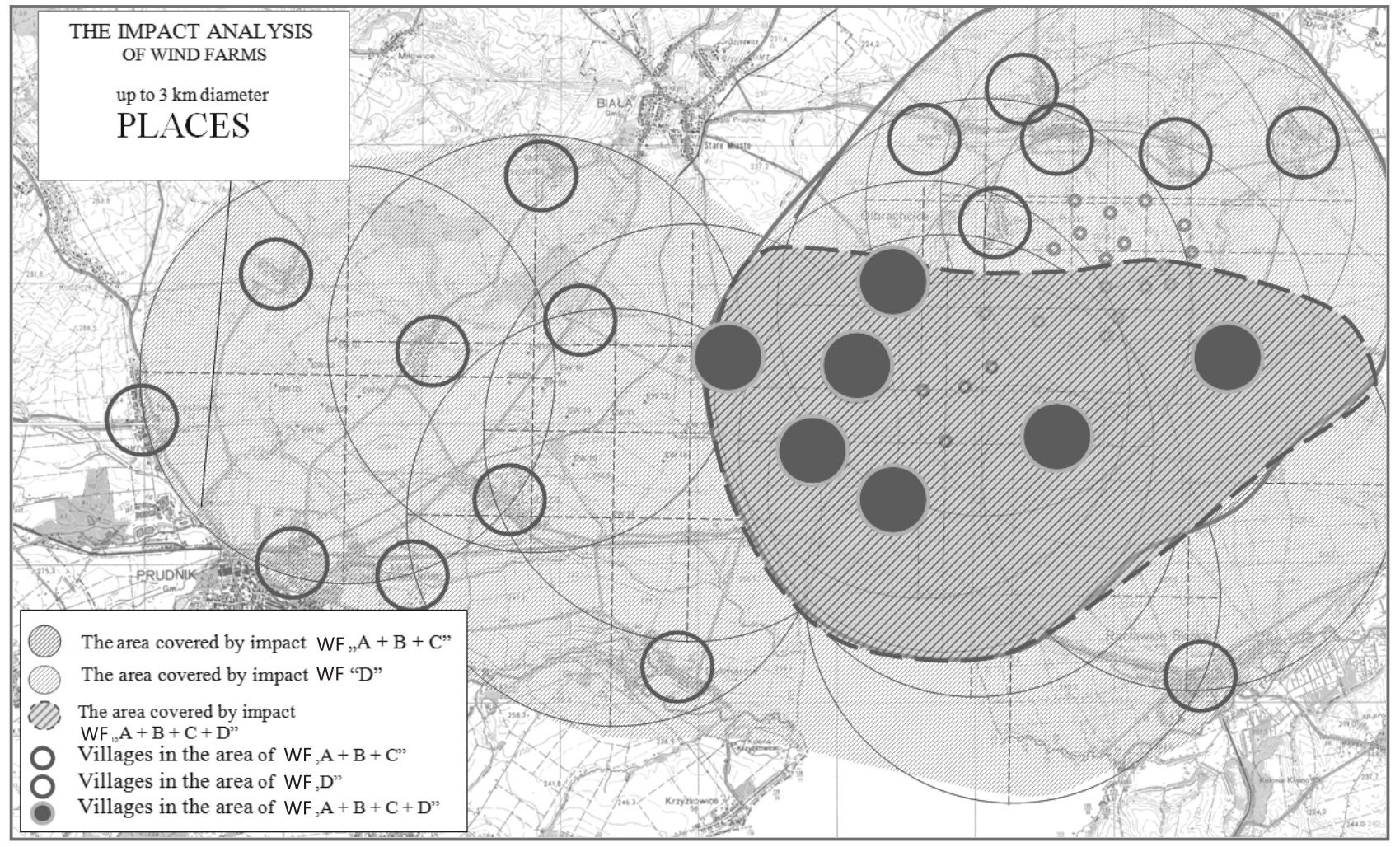

Fig. 6. The planned Lubrza Wind Farm (areas A, B, and C), Biała Wind Farm (area D) and the area covered by accumulated impact of the both farms. Own elaboration.

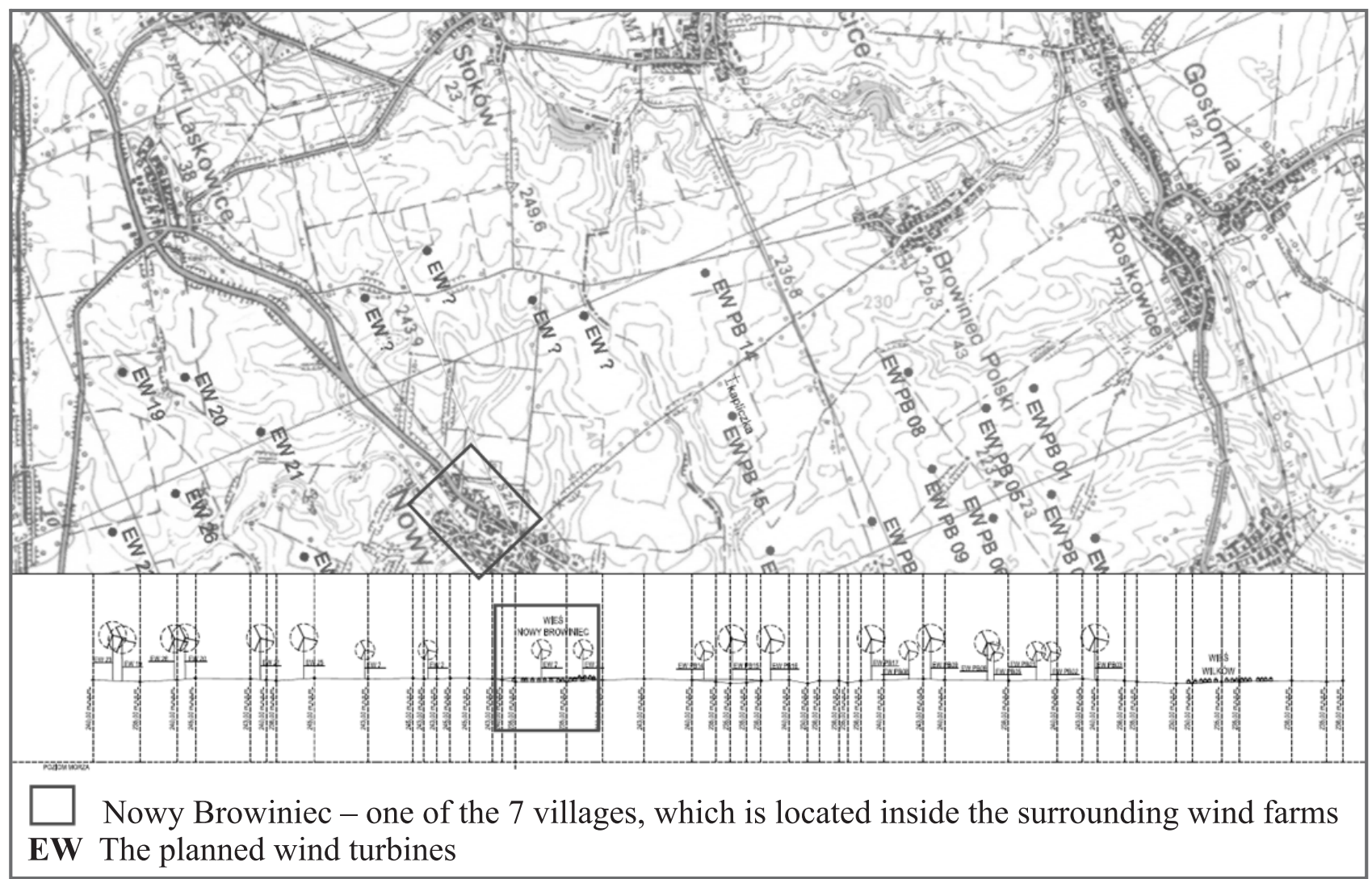

Fig. 7. Profile of the area affected both by Lubrza Wind Farm and Biała Wind Farm. Prepared by: T. Malczyk and G. Gołębiowski. 


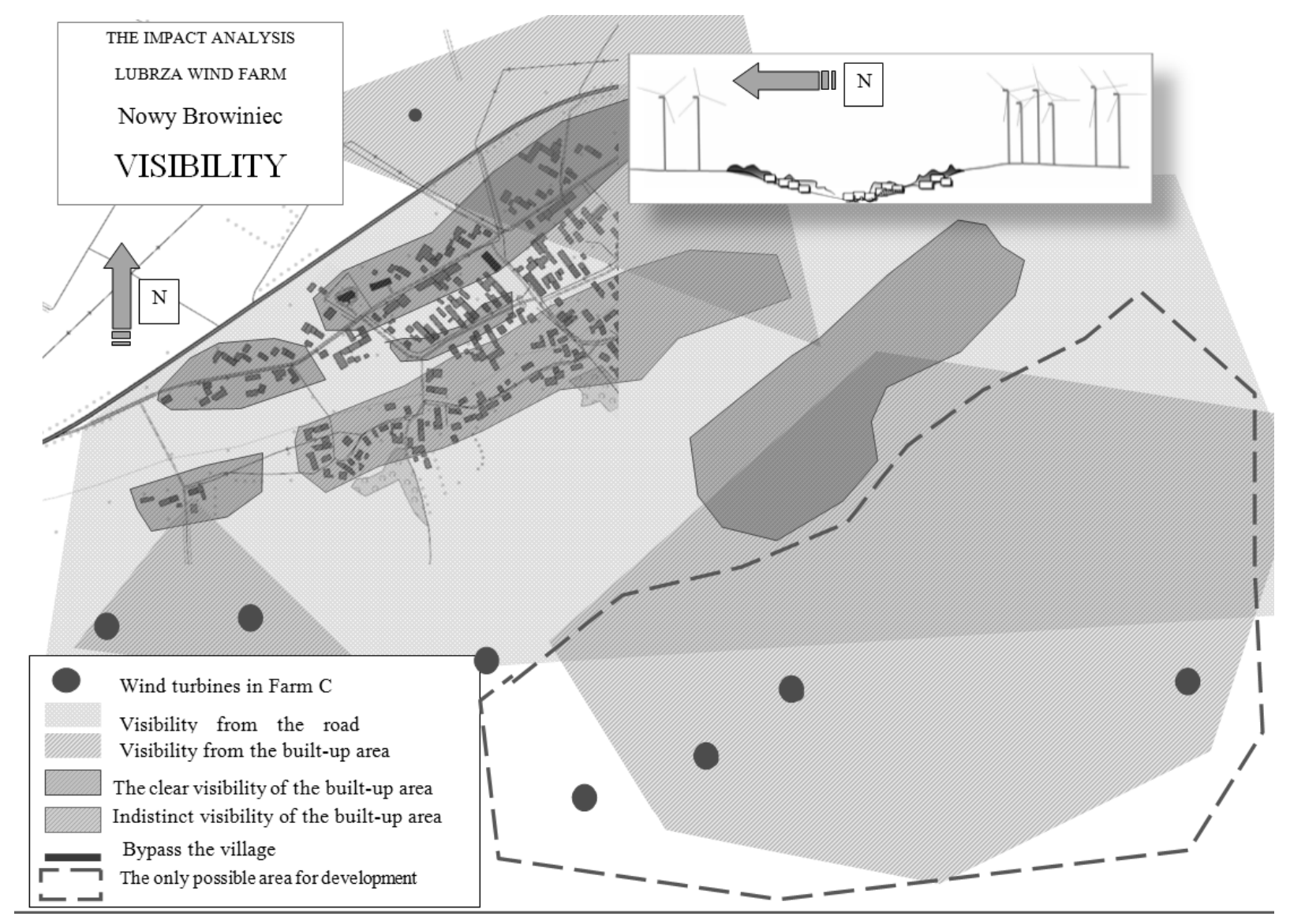

Fig. 8. Fields of visibility and possible directions of spatial development of Nowy Browiniec. Own elaboration.

wice - Wilków. Each of the aforementioned communes implements its own policy, according to its expectations. However, only on regional and local levels, particularly concerning social, landscape, and planning, do their actions (the effects of their actions) focus on one area. In the discussed case, assuming equidistance of $3 \mathrm{~km}$ (only the first interval of the impact on the environment $[2,6,39$, $41,50]$ ), in the immediate vicinity of the wind power station Lubrza (consisting of parts A, B, and C) there are 17 towns, and in the immediate vicinity of Biała Wind Farm there are 13 towns. As a result of overlapping of areas of the largest influence, seven towns are located in the vicinity of two farms. Eco-energetic anthropopressure created by the system in this area is exceptionally noticeable and may, apart from changes in perception of this place and its identity, discourage and even prevent its further development, in both the spatial and in demographic senses. It is especially important for Opolskie Province, where depopulation is underway.

Considering the planned location of both farms and the scope of their impact, a silhouette was marked at the common area of the whole spatial establishment (Fig. 7). It indicates that in the case of the execution of the whole project, seven towns will be "cut off" by the surrounding farms, which hinders their free spatial development, changes landscape values, and affects the current definition of genius loci, which is exemplified with a "new" identity from the point of view of society and the place. This affects in particular Nowy Browiniec (Fig. 8).

The planned location of the farm will hinder spatial development of the town, which develops mostly at its higher part (south), from where there is an exceptional view. Additionally, Nowy Browiniec is well connected with Nysa, Głuchołazy, Prudnik, Głogówek, Kędzierzyn-Koźle (eastwest axis), Głubczyce, and Opole (north-south axis), which substantially improves its attractiveness, especially in the case of the labour market. Limitation of spatial development possibilities results from space-blocking frames, i.e., from the northern side there is a beltway. It is also where construction of Biala Wind Farm is planned; from the southern side Lubrza Wind Farm construction is planned.

\section{Conclusions}

This particular case mentioned in the article exemplifies the problem of location of wind farms in an open landscape which, due to their dominant spatial role, require a proper approach to planning. Dichotomous position in the assessment of location of the farm is justified. On the one hand, it is a desired investment as a wind farm is a source of renewable energy and, on the other hand, it has on impact on the vicinity, which constantly influences space management and hence its planning. This problem will be systematically increasing along with designing and 
the location of repeated investments of this kind. For this reason, methodology of evaluation of the correctness of the farm location also in terms of landscape and spatial development (urban and rural) should be created [2, 31, $41,56,57]$. Additionally, assessment of location of a wind farm should not be restricted to a particular existing place, the place where the construction of the wind farm is planned should be also enriched and designed (prepared) for farm construction that will alleviate its visual and spatial influence. The development of wind farms can also have a significant impact on sustainable planning, particularly in terms of a bioclimatic, thermal comfort zone $[58,59]$ and even tourism activities [60]. As a result, in the future it will be possible to adapt spaces potentially relevant in terms of wind farm locations (areas of proper wind capacity, areas of proper terrain roughness, etc.) so as to ensure that it does not only minimize the probability of the conflicts caused by the process, but in some cases even makes the location of the planned wind power station more attractive.

This will enable fluent development of a wind power industry based on the basic principles of sustainable development in connection with scientific prediction and empirical resources. Therefore, a common space for the solution of the discussed problem should be created so that development of the wind power industry does not impede spatial development and vice versa.

In summary, the article proved the consistency of wind energy development with the process of sustainable planning and space management. It highlighted the necessity of simultaneous planning and assessment of the anticipated effects of the construction of wind farms. The article also proved the need to assess the impact of a wind farm on many areas, in particular on the possibility and direction of village and town spatial development.

\section{References}

1. JERPÅSEN G. B., LARSEN K. C. Visual impact of wind farms on culture heritage: A Norwegian case study, Environmental Impact Assessment Review, 31, 206, 2011.

2. MALCZYK T. Antropopresja ekoenergetyczna w procesie zmiany krajobrazu na przykładzie wybranych farm wiatrowych w Polsce (Ecopower anthropopression in the process of changing of the Landscape on the example of selected wind farms in Poland), Publishing House of Wrocław University of Environmental and Life Sciences, p. 7-14, 26-62, 163-187, 2013 [In Polish].

3. GROTH T. M., VOGT CH. A. Rural wind farm development: Social, environmental and economic features important to local residents, Renewable Energy, 63, 1, 2014.

4. ROOPALI P. Resisting and Reconciling Big Wind: Middle Landscape Politics in the New American West, Antipode, USA, 43 (3), 754, 2011.

5. MOLNAROVA K., SKLENICKA P., STIBOREK J., SVOBODOVA K., SALEK M., BRABEC E. Visual preferences for wind turbines: Location, numbers and respondent characteristics, Applied Energy, 92, 269, 2012.

6. MALCZYK T. Eco Energy Anthropopression in the Landscape for Example the Wind Park "Lipniki", Landscape Architecture, 36 (3), 37, 2012.
7. LISIK A. (ed.), Odnawialne źródła energii w architekturze (Renewable energy sources in architecture), Publishing House of Silesian University of Technology, Gliwice, 167, 2002. [In Polish].

8. FROST\&SULLIVAN, Favorable Winds Blow for Offshore Wind Power, PR Newswire US, California, USA, 1, 2012.

9. RYŃSKA E. D. Architect w procesie tworzenia harmonijnego środowiska (Architect in a process of creation of harmonious environment), Publishing House of Warsaw University of Technology, Warsaw, 11-25, 117-136, 2004 [In Polish].

10. KARDAS S.J., JASIŃSKA M. Społeczny wymiar zrównoważonego rozwoju organizacji (Social dimension of organization sustainable development), Studio Emka Publishing House, Warsaw, 15, 2010 [In Polish].

11. TORUŃSKI J., WYRĘBEK H. Zrównoważony rozwój regionów (Sustainable regions development), Studio Emka Publishing House, Warsaw, 105, 2011 [In Polish].

12. KULAS Z. Szanse i zagrożenia dla energetyki wiatrowej, Wiedza drogą do sukcesu - kreowanie innowacyjności (Opportunities and threats for the wind power industry, knowledge as a road to success innovation creation), Publishing House of PWSZ in Nysa, 91, 2010/11 [In Polish].

13. MIKOŚ J. Budownictwo ekologiczne (Ecological construction), Publishing House of Politechnika Śląska, Gliwice, 54, 2000 [In Polish].

14. SOBAŃSKI R., KABAT M, NOWAK W. Jak pozyskać ciepło z ziemi (How to acquire heat from the ground), Centralny Ośrodek informacji budownictwa, Warsaw, 13-20, 17-26, 2000 [In Polish].

15. KOM, Energia 2020 A Strategy for competitive, sustainable and secure energy, European Commission, Brussels, 7, 2010. [In Polish].

16. SZLACHTA J. Możliwości zastosowania odnawialnych źródeł energii na obszarach wiejskich (The possibilities of applying renewable energy sources in rural areas), [in:] Agritourism, renewable energy, eco-agriculture, environment shaping (ed. T Malczyk), Publishing House of PWSZ in Nysa, Nysa, 139, 2010. [In Polish].

17. ROMAŃSKI L. Przedstawienie możliwości wdrożenia konkretnych rodzajów OZE w gospodarstwach domowych z uwzględnieniem regionalnych uwarunkowań - Energia wiatru i wody, Konferencja OZE dla domu i biznesu (Presentation of possibilities of implementation of specific kinds of RSE in households taking into consideration regional conditions - Energy of wind and water, Conference for RSE house and business), ODR in Wrocław, 2010. [In Polish].

18. JANIKOWSKI R. Zarządzanie antropopresją w kierunku zrównoważonego rozwoju społeczeństwa i gospodarki (Management of anthropopression towards sustainable development of the society and economy), Difin, Warsaw, 12, 2004 [In Polish].

19. JANIKOWSKI R. Zarządzani ekologiczne (Ecological management), Akademicka Oficyna PLJ, Warsaw, 1999 [In Polish].

20. LENARTOWICZ K. Słownik o psychologii Architektury dla studiujących architekturę (Glossary of Architecture psychology for architecture students), Publishing House of Cracow University of Technology, Cracow, 97, 1997 [In Polish].

21. McCARTHY J. First World political ecology: Lessons from the Wise Use movement, Environment and Planning, 34, 1281, 2002

22. DUNCAN J. S. and DUNCAN N. G. Landscape of Privilege: The Politics of the Aesthetic in a American Suburb, Routledge, New York, 2004. 
23. CoEIWEP, Environmental Impacts of Wind-Energy Projects, Committee on Environmental Impacts of Wind Energy Projects, National Academies Press, Washington, p. 10-18, 48-90, 97-120, 2007

24. WEIGT M. Góry Opawskie, przydrożne kapliczki, krzyże i figury Projekt "Powiat Prudnicki-Mikroregion Krnovskitwórcze pogranicze" (Opawskie Mountains, wayside shrines, crosses and statues, Project "Prudnicki DistrictKrnovski Microregion-creative borderland"), Prudnik, 13, 2009 [In Polish]

25. ROOPALI P. Resisting and Reconciling Big Wind: Middle Landscape Politics in the New American West, Department of Environmental Studies, Macalester College, St Paul, MN, Antipode, USA, 43 (3), 754, 2011.

26. AusWEA i ACNT, Wind Farms and Landscape Values, Australian Wind Energy Association and Australian Council of National Trusts, Australia, 2, 2004.

27. FLAGA A. Inżynieria wiatrowa (Wind engineering), Arkady, Warsaw, 639, 2008 [In Polish].

28. YUANCHANG D., ZHI Y., SHA L. A review on scale and siting of wind farms in China, Wind Energy, 14, 463, 2011.

29. EWEA, Annual Report 2013, The European Wind Energy Association, 6, 2013

30. GWEC, Global Wind Report 2014, Global Wind Energy Council, Belgium, 7, 2014.

31. GAWLIKOWSKA A. Renewable energy in urban planning on the example of wind energy, Architecture and City Planning Committee, Polish Academy of Sciences, 2/2013, 148, 2013.

32. RADZIEWICZ W. Produkcja energii elektrycznej w elektrowni wiatrowej w zależności od potencjału wiatru na różnych wysokościach (Production of electric power in wind power stations depending on wind potential on various heights), Opole University of Technology, 1, 2009 [In Polish].

33. IMIGW. The Institute of Meteorology and Water Management, 1971-2001. Information of Opole Province in Brussels, Belgium, 2001. [In Polish].

34. DILLON CONSULTING LIMITED. McLean's Mountain Wind Farm Environmental Screening Report/Environmental Impact Statement, Toronto, Ontario, 2009.

35. KONDRACKI W. Geografia Polski-Mezoregiony fizycznogeogeaficzne (Geography of Poland - physical - geogeaphic mesoregions): PWN, Warsaw, 1994 [In Polish].

36. ALLEN W.M. Tools for Evaluating Wind Turbine Visibility, Technical Considerations in Siting Wind Developments: NWCC Research Meeting, Washington, 16, 2005.

37. HECKLAU J. Visual Characteristics of Wind Turbines, Technical Considerations in Siting Wind Developments: NWCC Research Meeting, Washington, 13, 2005

38. BADORA K.:Lokalizacja farm wiatrowych w południwej części województwa opolskiego a uwarunkowania przyrodniczo-krajobrazowe (Location of wind farms in the southern part of the Opolskie Province and natural landscape conditions), Inżynieria Ekologiczna No. 23, Technology Basics Department, Lublin University of Technology, 97, 2010 [In Polish].

39. STRYJECKI M., MILEŃCZUK K. Wytyczne w zakresie prognozowania oddziaływań na środowisko farm wodnych (Guidelines regarding forecasting of environmental impact of wind farms), General Directorate for Environmental Protection, Warsaw, 27, 2011 [In Polish].

40. MANCHADO C., OTERO C., GÓMEZ-JÁUREGUI V., ARIAS R. BRUSCHI V., CENDRERO A. Visibility analysis and visibility software for the optimisation of wind farm design, Renewable Energy 60, 388, 2013.
41. Scottish Natural Heritage, Siting and Designing windfarms in the landscape, p. 2, 17-43, 2009.

42. BAJEROWSKI T., BILOZOR A., CIEŚLAK I., SANETRA A., SZCZEPAŃSKA A. Ocena i wycena krajobrazu (Assessment and evaluation of the Landscape), Educatera Publishing House, Olsztyn, 30, 2007 [In Polish].

43. WEJCHERT K. Elementy kompozycji urbanistycznej (Elements of urban composition), Arkady, 171, 1984 [In Polish].

44. LUC Land Use Consultants, Landscape Sensitivity Analysis for Wind Energy Development in Bath and North East Somerset, London, 7, 2010.

45. HURTADO J.P., FERNANDEZ J., PARRONDO J.L., BLANCO E. Spanish method of visual impact evaluation in wind farms, Renewable and Sustainable Energy Review, 8 (5), 483, 2004.

46. SAŁYGA-RZOŃCA A, BURIAN M. Waloryzacja zabytkowego zasobu wsi województwa opolskiego - cele, metody, praktyka (Valorization of historic resources of villages of the Opole Province - goals, methods, practice), Regional Center of Research and Documentation of Monuments in Opole, 7, 2010.

47. MICHALIK-ŚNIEŻEK M., CHMIELEWSKI T.J. Analiza porównawcza kompozycji panoram widokowych Płaskowyżu Nałęczowskiego i Roztocza Zachodniego (Comparative analysis of view panoramas of Płaskowyż Nałęczowki and Roztocze Zachodnie), Problemy Ekologii Krajobrazu, XXXIII, 253, 2012 [In Polish].

48. RADOMSKI C. Agrometeorologia (Agrometeorology), PWN, Warszawa, 240, 1987 [In Polish].

49. MALCZYK T. Wytyczne do projektowania zieleni (Guidelines for greenery designing), Publishing House of PWSZ in Nysa, 19, 2005. [In Polish].

50. BUCHAN N. Visual Assessment of Windfarms: Best Practice, Edinburgh, University of Newcastle, p. 10-15, 17-20, 2002.

51. ROONŚ. Raport o oddziaływaniu na środowisko przedsięwzięcia PW Lipniki (Report on the environmental impact of the project Lipniki PW), Opole, 2007 [In Polish].

52. ROONŚ. Raport o oddziaływaniu na środowisko zespołu 2 elektrowni wiatrowych projektowanych w okolicy miejscowości Gostkowo, Natura (Environmental impact report of 2 planned wind power stations in the area of Gostkowo, Natura) (study by team), Gdynia, 48, 2009 [In Polish].

53. ROONŚ. Raport o oddziaływaniu przedsięwzięcia na środowisko Parku Elektrowni Wiatrowych "Staroźreby" (Environmental impact report of the Wind Power Stations Park "Staroźreby"), IDEA-ECO, Warsaw, p. 41, 124, 137, 167, 2011 [In Polish].

54. ROOŚ. Budowa Farmy Wiatrowej Lubrza wraz z infrastruktura towrzyszaca (Construction of the Lubrza Wind Farm along with the accompanying infrastructure), p. 37, 50-53, 87, 2012 [In Polish].

55. RESOLUTION. W sprawie uchwalenia miejscowego planu zagospodarowania przestrzennego terenów lokalizacji farmy wiatrowej na gruntach wsi Browiniec Polski - Rostkowice Wików (Adoption of the local spatial development plan of the areas of location of the wind farm in Browiniec Polski - Rostkowice - Wilków), Resolution No XXXVII/411/10 of the Municipal Council in Biała, 2010. [In Polish].

56. OTEROA C, MANCHADOA C, ARIAS R., BRUSCHI M.V., GÓMEZ-JÁUREGUI V., CENDRERO A. Wind energy development in Cantabria, Spain. Methodological approach, environmental, technological and social issues, Renewable Energy, 40, 137, 2012.

57. MANCHADOA C., OTEROA C., GÓMEZ-JÁUREGUI V., 
ARIAS R., BRUSCHI V., CENDRERO A. Visibility analysis and visibility software for the optimisation of wind farm design, Renewable Energy, 60, 388, 2013.

58. CETIN M. Using GIS analysis to assess urban green space in terms of accessibility: case study in Kutahya, International Journal of Sustainable Development \& World Ecology, 22 (5), 420, 2015.
59. CETIN M. Determining the bioclimatic comfort in Kastamonu City, Environmental Monitoring and Assessment, 187:640, 2015.

60. CETIN M. Evaluation of the sustainable tourism potential of a protected area for landscape planning: a case study of the ancient city of Pompeipolis in Kastamonu, International Journal of Sustainable Development \& World Ecology, 2015. 
